\title{
Carbohydrate metabolism of Xylella fastidiosa: Detection of glycolytic and pentose phosphate pathway enzymes and cloning and expression of the enolase gene
}

\author{
Agda Paula Facincani, Jesus Aparecido Ferro, João Martins Pizauro Jr., Haroldo Alves Pereira Jr., \\ Eliana Gertrudes de Macedo Lemos, Alessandro Luis do Prado and Maria Inês T. Ferro. \\ Departamento de Tecnologia, Faculdade de Ciências Agrárias e Veterinárias, \\ Universidade Estadual Paulista, Jaboticabal, Brazil.
}

\begin{abstract}
The objective of this work was to assess the functionality of the glycolytic pathways in the bacterium $X y / e l l a$ fastidiosa. To this effect, the enzymes phosphoglucose isomerase, aldolase, glyceraldehyde-3-phosphate dehydrogenase and pyruvate kinase of the glycolytic pathway, and glucose 6-phosphate dehydrogenase of the Entner-Doudoroff pathway were studied, followed by cloning and expression studies of the enolase gene and determination of its activity. These studies showed that $X$. fastidiosa does not use the glycolytic pathway to metabolize carbohydrates, which explains the increased duplication time of this phytopatogen. Recombinant enolase was expressed as inclusion bodies and solubilized with urea (most efficient extractor), Triton X-100, and TCA. Enolase extracted from $X$. fastidiosa and from chicken muscle and liver is irreversibly inactivated by urea. The purification of enolase was partial and resulted in a low yield. No enzymatic activity was detected for either recombinant and native enolases, aldolase, and glyceraldehyde-3-phosphate dehydrogenase, suggesting that $X$. fastidiosa uses the Entner-Doudoroff pathway to produce pyruvate. Evidence is presented supporting the idea that the regulation of genes and the presence of isoforms with regulation patterns might make it difficult to understand the metabolism of carbohydrates in $X$. fastidiosa.
\end{abstract}

Key words: enolase, Entner-Doudoroff, enzyme, glycolysis, Xylella fastidiosa.

Received: July 8, 2002; accepted: January 28, 2003.

\section{Introduction}

Xylella fastidiosa is a rough, nonmotile, nonsporeforming, Gram-negative, rod-shaped bacterium. It is present in the xylem of infected plants, and has been detected in many plants of economic importance such as sweet oranges, grapevines, plums, peaches, almonds, coffee, alfalfa, pears, and oak (Purcell and Hopkins, 1996). The bacterium obstructs the vascular system of the plant, causing water stress and a nutritional disorder. $X$. fastidiosa is transmitted by contaminated grafting or budwood and by different vector insects, mainly sharpshooters (Cicadellidae and Cercopidae) (Hartung et al., 1994).

The elucidation of infection mechanisms and plantpathogen interactions may contribute to the control of this phytopathogen. In this context, the strain $9 \mathrm{a} 5 \mathrm{c}$ of $X$. fastidiosa was the first plant phytopathogen completely se-

Send correspondence to Maria Inês T. Ferro. Universidade Estadual Paulista, Faculdade de Ciências Agrárias e Veterinárias de Jaboticabal, Departamento de Tecnologia, 14884-900 Jaboticabal, SP, Brazil. E-mail: mitferro@fcav.unesp.br. quenced by a consortium of researchers in Brazil (Simpson et al., 2000). Cosmid sequencing was one of the strategies used and this study focuses on the sequence of cosmid 02F10. The phytopathogen genome and information on the sequencing and cosmid annotation can be found on the Internet (http://onsona.lbi.dcc.unicamp.br/xf/).

The data generated by the sequencing of $X$. fastidiosa can be used for functional genetic studies. An analysis of the $X$. fastidiosa genome as related to the carbohydrate metabolism showed the presence of all genes encoding the enzymes which participate in the glycolysis, citric acid cycle and electron transport chain (Ferreira, 2000). On the other hand, the pentose phosphate pathway and gluconeogenesis seem to be incomplete. This could be a possible explanation for the long duplication time of this bacterium, since the available carbohydrates are also directed to the cell wall synthesis. In this context, this study attempted to establish whether these pathways are functional or whether there are alternative pathways. The functionality of the glycolytic pathway was evaluated by study the enzymes phosphoglucose isomerase, aldolase (glyceraldehyde-3- 
phosphate-lyase), and glyceraldehyde-3-phosphate dehydrogenase, whereas the Entner-Doudoroff pathway was evaluated by study the enzyme glucose 6-phosphate dehydrogenase. Cloning and determination of the enolase gene expression and activity (2-phospho-D-glycerate hydrolyase) were also performed.

Enolase is an entirely cytoplasmatic metalloenzyme with an approximate molecular weight of 40 to $50 \mathrm{kDa}$, requiring magnesium for its activity. It catalyzes the dehydration of 2-phosphoglycerate (PGA) to phosphoenolpyruvate (PEP) during glycolysis, and also the reverse reaction, hydration of PEP to PGA, during gluconeogenesis (Wold, 1971). The gene for this enzyme was identified in cosmid 02F10 and called XF1291.

\section{Material and Methods}

\section{Enolase cloning, expression and purification}

The nucleotide sequence of $X$. fastidiosa enolase was cloned by PCR products. Two forward primers with a $N d e \mathrm{I}$ restriction site were synthesized (Enolase F- 5' CGT TTT CTT ACA TAT GAT G 3' and Enolase 32F- 5' GTT GAC TGG ACA TAT GAC CGC TAT TGC C 3'), as well as one reverse primer with a Hind III restriction site (Enolase R- 5, GCC AGT TAC AAG CTT ATC AGG ACT T 3'), in order to facilitate the cloning into the expression vector. These two combinations of primers allowed the amplification of the gene, beginning with two possible initiation methionines, one at position 1 , and the other at position 32 . A fourth primer (Enolase 396- 5' AAT AAG GGG CGT TTG GGG GCT 3') was synthesized at position 396, to help the sequencing. Amplification was performed by a Perkin Elmer 2400 thermal cycler, using $100 \mathrm{ng}$ of cosmidial DNA (02F10) harboring the enolase gene of $X$. fastidiosa, 5 pmoles of each primer, $1 \mathrm{U}$ of Taq DNA Polimerase (Gibco), $200 \mu \mathrm{M}$ of dNTPs, $50 \mathrm{mM}$ of $\mathrm{MgCl}_{2}$ and 10x Taq buffer. The following protocol was used: an initial denaturation step of $2 \mathrm{~min}$ at $94{ }^{\circ} \mathrm{C}$, followed by 35 cycles of 90 s. at $94{ }^{\circ} \mathrm{C} ; 30 \mathrm{~s}$ at $54{ }^{\circ} \mathrm{C}$; and $90 \mathrm{~s}$ at $72{ }^{\circ} \mathrm{C}$. The amplified fragments were loaded onto a $0.8 \%$ lowmelting-point (LMP) agarose gel, recovered and purified according to Birren et al. (1997). Afterwards, the fragment was cloned in a $\mathrm{T}$ vector, using a pGEMT System II kit (Promega), as recommended by the manufacturers. Then an E. coli DH10B strain was transformed by electroporation (Bio Rad Gene Pulser II), using $50 \mathrm{mF}$ of capacitance, $200 \Omega$ low range, $\infty \Omega$ high range and adjustment to $1.5 \mathrm{kV}$. Plasmid minipreps were prepared from the colonies (Griffin and Griffin, 1993), and $0.5 \mu \mathrm{g}$ of the obtained DNA were digested with the restriction endonucleases Hind III and Nde I (Biolabs), as recommended by the manufacturers, to confirm the presence of the insert. The clones with inserts of expected size were sequenced using a Big Dye Terminator kit (ABI-Perkin Elmer), with 5 pmoles of primers T7 and SP6 (specific for T vector), $400 \mathrm{ng}$ of DNA, $2 \mu \mathrm{L}$ of Big
Dye Terminator, $6 \mu \mathrm{L}$ of $2.5 \mathrm{x}$ buffer $(200 \mathrm{mM}$ of Tris- $\mathrm{HCl}$ $\mathrm{pH} 9.0 ; 5.0 \mathrm{mM}$ of $\mathrm{MgCl}_{2}$ ) and the following protocol: initial denaturation at $96^{\circ} \mathrm{C}$ for $2 \mathrm{~min}$, and 39 cycles of $30 \mathrm{~s}$ at $96{ }^{\circ} \mathrm{C}, 15 \mathrm{~s}$ at $50^{\circ} \mathrm{C}$, and $4 \mathrm{~min}$ at $60^{\circ} \mathrm{C}$. The amplification product was analyzed in an ABI Prism 377 DNA Automated Sequencer (Perkin-Elmer). After confirming by sequencing the correct clone of each construction, a largescale preparation of DNA was made, using the WizardR Plus Maxipreps DNA Purification System Kit (Promega), as recommended by the manufacturer. Five micrograms of each DNA sample were digested with Hind III and Nde I, loaded onto a $0.8 \%$ LMP agarose gel, recovered and purified (Birren et al., 1997). The fragments were subcloned in the expression vector $\mathrm{pET} 3 \mathrm{a}$, which had been previously digested with the endonucleases Hind III and Nde I. The proportion used was 4 volumes of the vector for 1 volume of the insert, $2 \mu \mathrm{L}$ of $10 \mathrm{x}$ buffer for T4 DNA ligase, $0.5 \mu \mathrm{L}$ of T4 DNA ligase from Bio Labs $(400 \mathrm{U} / \mu \mathrm{L})$, in a final volume of $20 \mu \mathrm{L}$. After $16 \mathrm{~h}$ at $15^{\circ} \mathrm{C}, 4 \mu \mathrm{L}$ of the DNA solution were used in the electroporation of $40 \mu \mathrm{L}$ of BL21 (DE3) pLYS-S E. coli cells. The colonies were cultured for $3 \mathrm{~h}$ in $3 \mathrm{~mL}$ of 2 XTY medium containing carbenicillin and chloramphenicol at $200 \mu \mathrm{g} / \mathrm{mL}$, plus isopropylthiogalactoside (IPTG) in a concentration of $0.4 \mathrm{mM}$ as an inducer (Sambrook et al., 1989), until the $\mathrm{OD}_{600}$ was 0.8 to 1.0 . Cells were centrifuged $\left(16,000 \mathrm{~g}\right.$ for $5 \mathrm{~min}$ at $\left.4{ }^{\circ} \mathrm{C}\right)$ and lysed with $50 \mu \mathrm{L}$ of $2 \mathrm{x}$ lysis buffer $(125 \mathrm{mM}$ Tris- $\mathrm{HCl} \mathrm{pH}$ $6.8 ; 4 \% \mathrm{w} / \mathrm{v}$ SDS; $20 \% \mathrm{v} / \mathrm{v}$ glycerol; $5 \% \mathrm{v} / \mathrm{v} \beta$-mercaptoethanol; $0.01 \% \mathrm{w} / \mathrm{v}$ bromophenol blue). After heating at $95{ }^{\circ} \mathrm{C}$ for $5 \mathrm{~min}$, they were centrifuged again $(16,000 \mathrm{~g}$ for $10 \mathrm{~min}$ ), and $15 \mu \mathrm{L}$ of the supernatant were loaded onto a $12 \%$ SDS-PAGE polyacrylamide gel (Laemmli, 1970).

Large-scale enolase expression studies were done according to Monteiro et al. (1994), and inclusion bodies were solubilized by using urea (Glover and Hames, 1995). Other denaturing agents less chaotropic than urea were also tested, such as $3 \%$ Triton X-100 and $2.5 \mathrm{M}$ sodium trichloroacetate (TCA). To the induced and lysed bacteria, 10 volumes of $\mathrm{pH} 8,0$ buffer $\left(50 \mathrm{mM}\right.$ Tris $\mathrm{HCl} ; 2.0 \mathrm{mM} \mathrm{MgSO}_{4}$; $0.1 \mathrm{mM}$ EDTA; $8.0 \mathrm{M}$ urea and $1.4 \mathrm{mM} \beta$-mercaptoethanol) were added, followed by centrifugation for $45 \mathrm{~min}$ at $6,500 \mathrm{~g}$ at room temperature. The supernatant was loaded onto a DEAE-Sepharose Fast Flow column (Pharmacia) $(18 \times 2 \mathrm{~cm})$ balanced with $10 \mathrm{mM}$ Tris- $\mathrm{HCl} \mathrm{pH} 9.0,5 \mathrm{mM}$ $\mathrm{MgSO}_{4}, 1 \mathrm{mM}$ EDTA, $1 \mathrm{mM} \beta$-mercaptoethanol, and $8 \mathrm{M}$ urea, at a flow rate of $8 \mathrm{~mL} / \mathrm{h}$. Enolase was eluted using $\mathrm{NaCl}$ gradient $(0-250 \mathrm{mM})$. Fractions containing enolase were collected and dialyzed in $15 \mathrm{mM} \mathrm{NaH} \mathrm{NO}_{4} /$ $\mathrm{Na}_{2} \mathrm{HPO}_{4}$, pH 6.2 buffer containing $3 \mathrm{mM} \mathrm{MgSO} 4,1 \mathrm{mM}$ $\beta$-mercaptoethanol, with decreasing amounts of urea $(6,4$, $2,1$, and $0 \mathrm{M})$. Finally, the extract was loaded onto a CM-Sepharose column (Pharmacia) $(18 \times 2 \mathrm{~cm})$ at a flow rate of $8 \mathrm{~mL} / \mathrm{h}$ at $4{ }^{\circ} \mathrm{C}$. The absorbance of the eluate frac- 
tions was determined at $280 \mathrm{~nm}$, and the protein profile was analyzed in $12 \%$ SDS-PAGE polyacrylamide gels.

\section{Growth of $X$. fastidiosa, DH5 $\alpha$ and JM101 E. coli strains, and enolase extraction}

$X$. fastidiosa was grown at $30^{\circ} \mathrm{C}$ and $150 \mathrm{rpm}$ for 7 days in $100 \mathrm{~mL}$ of $\mathrm{XDM}_{2}$ medium (Lemos et al., 2002). The cells were harvested by centrifugation $(6,500 \mathrm{~g}$ for $15 \mathrm{~min}$ at $4{ }^{\circ} \mathrm{C}$ ) and resuspended in $1 \mathrm{~mL}$ of TE-sucrose buffer (50 mM Tris-HCl pH 8.0; 1 mM EDTA pH 8.0; 25\% $\mathrm{w} / \mathrm{v}$ sucrose). They were sonicated using a Branson Sonifier 250 apparatus (pulses of $10 \mathrm{~s}, 60 \mathrm{~W}$, for $6 \mathrm{~min}$ ), and centrifuged at $6,500 \mathrm{~g}$ for $5 \mathrm{~min}$ at $4{ }^{\circ} \mathrm{C}$.

E. coli strains $\mathrm{DH} 5 \alpha$ and JM101 were grown in $500 \mathrm{~mL}$ of minimum medium (Sambrook et al., 1989) at $37{ }^{\circ} \mathrm{C}$ and $250 \mathrm{rpm}$ for $16 \mathrm{~h}$. Cells were centrifuged at $6,500 \mathrm{~g}$ for $15 \mathrm{~min}$ at $4{ }^{\circ} \mathrm{C}$ and resuspended in $20 \mathrm{~mL}$ of TE-sucrose buffer. Lysis was performed 4 times in a French Pressure Cell Press (16,000 psi), and the lysed cells were centrifuged at $6,500 \mathrm{~g}$ for $15 \mathrm{~min}$ at $4{ }^{\circ} \mathrm{C}$. The pellet was discarded and the supernatant was used for further studies.

\section{Extraction of enolase from chicken muscle and liver}

Each muscle sample was homogenized with $10 \mathrm{mM}$ Tris- $\mathrm{HCl}$, $\mathrm{pH} 9$, containing $0.5 \mathrm{mM} \mathrm{MgSO}_{4}, 1 \mathrm{mM}$ EDTA and $1 \mathrm{mM} \beta$-mercaptoethanol $(10 \mathrm{~mL} / \mathrm{g})$ in an Ultra Turrax tissue homogenizer (Marconi), at $4{ }^{\circ} \mathrm{C}$. One $\mathrm{mL}$ of the homogenate was centrifuged at $16,000 \mathrm{~g}$ for $10 \mathrm{~min}$ at $4{ }^{\circ} \mathrm{C}$, and the supernatant was used to evaluate enolase activity.

The same procedure was used to obtain the crude extract of another muscle sample with $5 \mathrm{mM} \mathrm{NaH}_{2} \mathrm{PO}_{4} /$ $\mathrm{Na}_{2} \mathrm{HPO}_{4}, \mathrm{pH} 6.2,3 \mathrm{mM} \mathrm{MgSO}$, and $1 \mathrm{mM} \beta$-mercaptoethanol. Liver samples were prepared in the same manner.

Two protocols were followed to prepare the liver and muscle samples. By the first one, one sample of each tissue was homogenized with $10 \mathrm{mM}$ Tris- $\mathrm{HCl}, \mathrm{pH}$ 9, containing $0.5 \mathrm{mM} \mathrm{MgSO} 4,1 \mathrm{mM}$ EDTA and $1 \mathrm{mM} \beta$-mercaptoethanol $(10 \mathrm{~mL} / \mathrm{g})$ in an Ultra Turrax tissue homogenizer (Marconi), at $4{ }^{\circ} \mathrm{C}$. One $\mathrm{mL}$ of the homogenate was centrifuged at $6,500 \mathrm{~g}$ for $10 \mathrm{~min}$ at $4{ }^{\circ} \mathrm{C}$, and the supernatant was used to evaluate enolase activity. By the second protocol, homogenization was done using $5 \mathrm{mM} \quad \mathrm{NaH}_{2} \mathrm{PO}_{4} /$ $\mathrm{Na}_{2} \mathrm{HPO}_{4}$, pH 6.2, $3 \mathrm{mM} \mathrm{MgSO}_{4}$, and $1 \mathrm{mM} \beta$-mercaptoethanol. The liver and muscle samples were centrifuged as described above, and the supernatant was used to determine enolase activity.

\section{Enolase activation}

Since enolase was expressed as inclusion bodies, a treatment with guanidine- $\mathrm{HCl}$ was necessary to allow the extraction of the enzyme in an active folded configuration. In vitro recombinant enolase activation was carried out according to Vuillard and Freeman (2001). Briefly, the pellet from a liter of bacterial suspension was resuspended in $20 \mathrm{~mL}$ of $50 \mathrm{mM}$ HEPES-NaOH pH 7.5, 0.5 M NaCl, $1 \mathrm{mM}$
PMSF, $5 \mathrm{mM}$ DTT containing $0.35 \mathrm{mg} / \mathrm{mL}$ lysozyme, and then incubated for $30 \mathrm{~min}$ at $20^{\circ} \mathrm{C}$. Triton $\mathrm{X}-100$ was added to a concentration of $1 \%(\mathrm{v} / \mathrm{v})$, followed by ultrasound sonication in bursts of $30 \mathrm{~s}$ and cooling, until the solution cleared. The extract was treated with DNase I $(20 \mu \mathrm{g} / \mathrm{L})$ for $1 \mathrm{~h}$ at $37^{\circ} \mathrm{C}$, and centrifuged at $30,000 \mathrm{~g}$ for $30 \mathrm{~min}$ at $4{ }^{\circ} \mathrm{C}$. The pellet (inclusion bodies) was washed twice with TBS containing $1 \%$ Triton $\mathrm{X}-100$, centrifuged at $30,000 \mathrm{~g}$ for 30 min at $4{ }^{\circ} \mathrm{C}$, and then solubilized for $1 \mathrm{~h}$ at $4{ }^{\circ} \mathrm{C}$ in $2 \mathrm{~mL}$ of $50 \mathrm{mM}$ HEPES-NaOH pH 7.5, $6 \mathrm{M}$ guanidine- $\mathrm{HCl}$, $25 \mathrm{mM}$ DTT. After centrifugation at $100,000 \mathrm{~g}$ for $10 \mathrm{~min}$, the insoluble material was removed. The protein concentration in the supernatant was adjusted to $1 \mathrm{mg} / \mathrm{mL}$ using $50 \mathrm{mM}$ HEPES-NaOH pH 7.5, $6 \mathrm{M}$ guanidine $\mathrm{HCl}, 25 \mathrm{mM}$ DTT, and then diluted (1:10) as quickly as possible with cold folding buffer (50 mM HEPES pH 7.5, $0.2 \mathrm{M} \mathrm{NaCl}$, $1 \mathrm{mM}$ DTT, $1 \mathrm{M}$ NDSB201). After $1 \mathrm{~h}$ at $4{ }^{\circ} \mathrm{C}$, it was dialyzed overnight against $15 \mathrm{mM} \mathrm{NaH}{ }_{2} \mathrm{PO}_{4} / \mathrm{Na}_{2} \mathrm{HPO}_{4}, \mathrm{pH} 6.2$ buffer containing $3 \mathrm{mM} \mathrm{MgSO}$ and $1 \mathrm{mM} \beta$-mercaptoethanol, at $4{ }^{\circ} \mathrm{C}$.

\section{Determination of enolase activity and stability}

Enolase activity was determined according to Kurstrzeba et al. (2000), using phosphoenolpyruvate (PEP) and 2-phosphoglycerate (2-PGA) as substrates. Total protein in the supernatants of $X$. fastidiosa, E. coli, and chicken tissue extracts (liver and muscle) was determined according to Hartree (1972). Ten microliters of the supernatants of $X$. fastidiosa, E. coli and chicken tissue extracts (liver and muscle) were used to determine enzyme activity, by monitoring for five days. Enolase stability was evaluated by adding $8 \mathrm{M}$ of urea to the supernatants and then removing it by dialysis at $4{ }^{\circ} \mathrm{C}$ against $15 \mathrm{mM} \mathrm{NaH} \mathrm{PO}_{4} / \mathrm{Na}_{2} \mathrm{HPO}_{4}$, $\mathrm{pH} 6.2$ buffer containing $3 \mathrm{mM} \mathrm{MgSO}$ and $1 \mathrm{mM} \beta$-mercaptoethanol. Enolase activity was determined before and after the addition of urea, and also after its removal.

\section{Growth and preparation of crude extract of $X$. fastidiosa enzymes}

The pre-inoculum of $X$. fastidiosa was obtained from cultures in solid $\mathrm{XDM}_{2}$ medium (Lemos et al., 2002). This medium is composed of $\mathrm{K}_{2} \mathrm{HPO}_{4}(2.1 \mathrm{~g} / \mathrm{L}), \mathrm{KH}_{2} \mathrm{PO}_{4}$ $(0.8 \mathrm{~g} / \mathrm{L}), \mathrm{MgSO}_{4} .7 \mathrm{H}_{2} \mathrm{O}(0.4 \mathrm{~g} / \mathrm{L}), \mathrm{Fe}^{2+}$ pyrophosphate $(0.125 \mathrm{~g} / \mathrm{L})$, glucose $(10 \mathrm{~g} / \mathrm{L})$, vitamin solution $(10 \mathrm{~mL} / \mathrm{L})$, phenol red $(0.004 \mathrm{~g} / \mathrm{L})$, and the amino acids glutamine $(0.04 \mathrm{~g} / \mathrm{L})$, methionine $(0.004 \mathrm{~g} / \mathrm{L})$ and asparagine $(0.01 \mathrm{~g} / \mathrm{L})$.

The enzymes involved in carbohydrate utilization were activated as follows, $X$. fastidiosa was grown in $100 \mathrm{~mL}$ of three different liquid media at $30^{\circ} \mathrm{C}$ and $150 \mathrm{rpm}$ for 10 days, and in a fourth solid medium at $30^{\circ} \mathrm{C}$ for 10 days. The liquid medium $\mathrm{XDM}_{2}$ (medium1) was used as a control and as a basis to evaluate the utilization of carbon sources in the modified media. The rationale was that, without carbon from amino acids, glucose would be the only 
carbon source available to the bacteria in the medium. Therefore, no amino acids were added to medium $\mathrm{XDM}_{2}$, and other nitrogen sources were added to media 2, 3, and 4, respectively, $\mathrm{KNO}_{3}(0.2 \mathrm{~g} / \mathrm{L}), \mathrm{NH}_{4} \mathrm{NO}_{3}(0.2 \mathrm{~g} / \mathrm{L})$, and $\mathrm{KNO}_{3}(0.2 \mathrm{~g} / \mathrm{L})$. Agar was added at a concentration of $15 \mathrm{~g} / \mathrm{L}$, and the $\mathrm{pH}$ was adjusted to 6.8. E. coli $\mathrm{DH} 5 \alpha$ was grown in $100 \mathrm{~mL}$ minimum medium and used as a standard.

After cultivation in the different media, the bacteria were centrifuged $\left(16,000 \mathrm{~g}\right.$ for $5 \mathrm{~min}$ at $\left.4{ }^{\circ} \mathrm{C}\right)$, washed twice with saline $(\mathrm{NaCl} 0.85 \%)$ and resuspended in $0.5 \mathrm{~mL}$ of an appropriate buffer (Tris- $\mathrm{HCl} 0.1 \mathrm{M} \mathrm{pH} \mathrm{7.2,} 5 \mathrm{mM} \mathrm{MgCl}_{2}$, $15 \%$ glycerol, and $0.1 \% \beta$-mercaptoethanol). The cell pellets were resuspended in the same buffer containing $1 \mathrm{mg} / \mathrm{mL}$ of lysozyme and incubated at room temperature for $10 \mathrm{~min}$. The suspension was centrifuged $(16,000 \mathrm{~g}$ for $5 \mathrm{~min}$ at $4{ }^{\circ} \mathrm{C}$ ), and the pellet was resuspended in sonication buffer (0.1 M Tris- $\mathrm{HCl} \mathrm{pH} 8.8$ with $15 \%$ glycerol). After sonication with a Branson Sonifier 250 apparatus (pulses of $10 \mathrm{~s}, 60 \mathrm{~W}$ for $10 \mathrm{~min}$ ) and centrifugation at 16,000 $\mathrm{g}$ for 5 min at $4{ }^{\circ} \mathrm{C}, 50 \mu \mathrm{L}$ of $X$. fastidiosa extracts and $5 \mu \mathrm{L}$ of $E$. coli $\mathrm{DH} 5 \alpha$ supernatant samples were used for enzyme studies.

\section{Polyacrylamide gel electrophoresis}

Enzymes were electrophoresed in $10 \%$ gels at $4{ }^{\circ} \mathrm{C}$ (Davis, 1964), and the activities of phosphoglucose isomerase (PGI - EC 5.3.1.9), glucose 6-phosphate dehydrogenase (G6PDH - EC 1.1.1.49), aldolase or glyceraldehyde-3-phosphato-lyase (ALD - EC 4.1.2.1.3), glyceraldehyde-3-phosphate dehydrogenase (GAPDH EC 1.2.1.1.2), and pyruvate kinase (PK - EC 2.7.1.40) were evaluated according to Alfenas (1998), using substrates specific for each enzyme.

\section{Results and Discussion}

It is usually difficult to obtain soluble proteins when they are expressed in prokaryotes such as E. coli, because inclusion bodies may be formed. These are insoluble protein aggregates composed of inadequately folded proteins that become inactive (Vuillard and Freeman, 2001). However, the solubilization of expressed proteins can be obtained under denaturing conditions. The most challenging point is to obtain a natively folded protein that shows biological activity (Vuillard and Freeman, 2001). The expression of $X$. fastidiosa enolase was no exception, and the solubilization of the inclusion bodies was attempted with $8 \mathrm{M}$ urea, Triton X-100, and TCA. The results showed that Triton X-100 and TCA were not efficient in rupturing the membrane of the inclusion bodies (data not shown). Thus, enolase was extracted from the inclusion bodies with urea, which was the most efficient denaturing agent.

Using the BLASTP tool from NCBI, similarity comparisons between the enolase of $X$. fastidiosa and of other eukaryotes and prokaryotes confirmed that the initial methionine was that located at position 32, indicating that the X. fastidiosa sequence was 1290 bp long. This methionine is the initial codon in all compared organisms.

Since enolase was expressed by both constructions as inclusion bodies, other experiments were performed with the enolase gene that was 1386 bp long. However, after the inclusion bodies were lysed by urea, the enzyme was only partially purified and the yield was low.

The electrophoretic protein profile obtained during the expression and purification of enolase is shown in Figure 1 . Ion-exchange chromatography did not remove all contaminating proteins, and the enolase obtained by this procedure presented a low degree of purity (Figure 1). Expressed and purified enolase showed no enzymatic activity, and other tests were then performed to investigate possible reasons for this lack of activity.

The bacterium cultured in the $\mathrm{XDM}_{2}$ medium showed no native enolase activity, suggesting that, in X. fastidiosa, the carbohydrate metabolism does not involve the glycolytic pathway. This hypothesis is based on the fact that the enolase extracted from chicken muscle and liver did show enzymatic activity in the presence of the substrates phosphoenolpyruvate (PEP) and 2-phosphoglycerate (2PGA) (Table 1), and was stable for five days. Besides, DH5 $\alpha$ and JM101 E. coli strains also showed enolase activ-

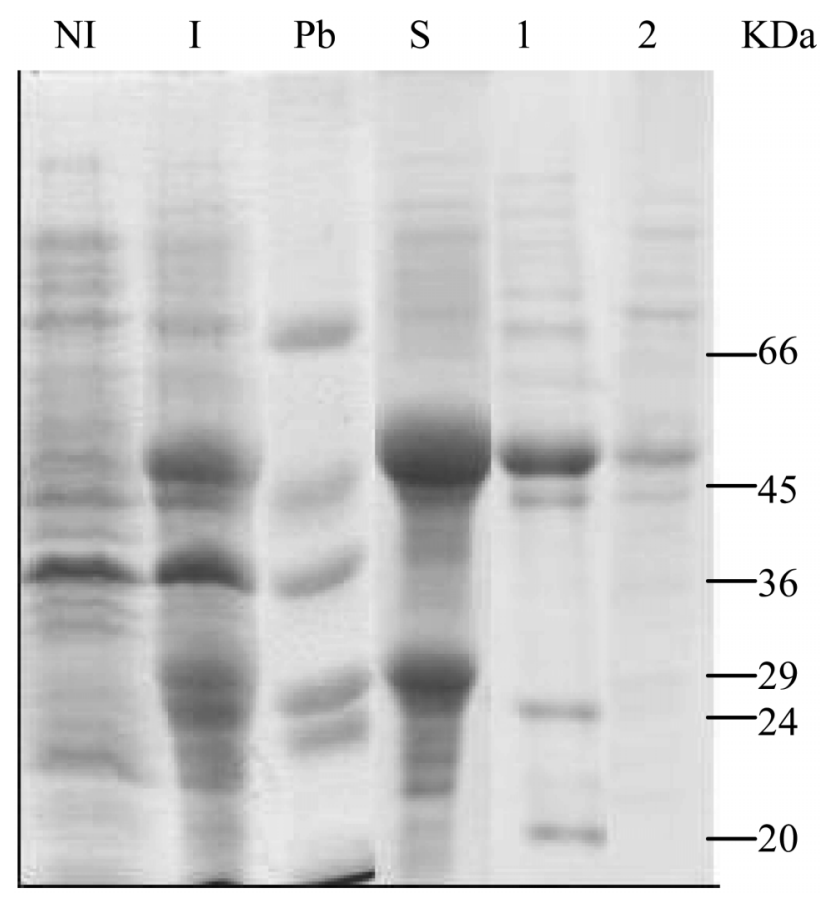

Figure 1 - Electrophoretic protein profile of the stages of enolase purification. Electrophoresis was performed using $12 \%$ SDS-PAGE polyacrylamide gel, staining was done with Coomassie Blue. Samples loaded onto the gel were: $15 \mu \mathrm{L}$ non-induced sample (NI), $5 \mu \mathrm{L}$ induced sample (I), $15 \mu \mathrm{L}$ supernatant $(\mathrm{S}), 10 \mu \mathrm{L}$ proteic fractions after purification in DEAE column (1), $15 \mu \mathrm{L}$ proteic fractions after purification in CM column (2). $\mathrm{Pb}-$ low standard molecular weight in $\mathrm{kDa}$. 
ity using the two substrates, indicating that enolase is bifunctional (Table 1).

The addition of urea and its removal by dialysis in enolase samples taken from chicken muscle and liver demonstrated that urea is the most efficient extracting agent. Nevertheless, it denatured enolase irreversibly and can therefore not be used to extract enolase from inclusion bodies.

The study of the effect of guanidine on the activation of proteins present in inclusion bodies revealed that this is also an efficient enolase denaturing agent, since no recombinant enolase activity was observed after activation experiments.

Since neither the recombinant nor the native enolase of $X$. fastidiosa showed any activity, some enzymes of the glycolytic and the Entner-Doudoroff pathways were chosen to evaluate the possible alternative carbohydrate metabolism pathway in this microorganism.

\section{Analysis of the activity of glycolytic pathway enzymes}

The activity of these enzymes is shown in Table 2. Surprisingly, the enzymes of the glycolytic pathway (aldolase and glyceraldeyde-3-phosphate dehydrogenase) were not detected. Nevertheless, glucose-6-phosphate dehydrogenase activity was detected; suggesting that $X$. fastidiosa uses the Entner-Doudoroff pathway to produce pyruvate. Another finding corroborates this hypothesis: The $X$. fastidiosa genome showed no ORFs (open reading frames) with products similar to phosphoglucanate dehydrogenase. Thus, it would be impossible to use the pentose pathway to produce ribose-5-phosphate. A second possibility worth considering is that the growth conditions of the bacteria might affect the regulation of the genes involved in carbohydrate metabolism. The results obtained for the activity of the enzymes extracted in media 2 and 4 showed the same pattern in the two different growth conditions tested, i.e., a more aerated environment (liquid medium) or a less aerated environment (solid medium). This may be explained by the fact that $X$. fastidiosa shows aerobic respiration in high aeration levels, but not in limiting oxygen conditions, since it has no high oxygen affinity cytochrome (Bhattacharyya et al., 2002). Besides, the glycolytic enzymes are difficult to be detected, due to the influence of a great range of factors, such as methodology, stage of development of the organism, ingredients of culture media, stress, and growth conditions. These can result in a complex situation that elucidates the quantitative relationships and respective metabolic functions, and also regulating properties of different isoforms (Rivoal et al., 2002).

The use of carbohydrates, especially glucose, as a source of carbon and energy is almost universal among bacteria, Archaea bacteria and eukaryotes. However, carbohydrate metabolism differs considerably among them (Romano and Conway, 1996). In almost all modern bacte-

Table 2 - Enzymatic activities of phosphoglucose isomerase (PGI-EC 5.3.1.9), glucose 6-phosphate dehydrogenase (G6PDH-EC 1.1.1.49), aldolase or glyceraldehyde-3-phosphate-lyase (ALD-EC 4.1.2.1.3), glyceraldehyde-3-phosphate dehydrogenase (GAPDH-EC 1.2.1.1.2), and pyruvate kinase (PK-EC 2.7.1.40), using X. fastidiosa cultured in media 1, 2, 3 and 4, and E. coli DH5 $\alpha$ as a standard, cultured in minimum medium (medium 5). Positive sign (+) indicates presence; negative sign (-) indicates absence.

\begin{tabular}{lccccc}
\hline & \multicolumn{5}{c}{ Enzymatic activities } \\
\cline { 2 - 6 } $\begin{array}{l}\text { Culture } \\
\text { medium }\end{array}$ & G6PDH & PGI & GAPDH & ALD & PK \\
\hline 1 & + & + & - & - & + \\
2 & + & + & - & - & + \\
3 & + & + & - & - & + \\
4 & + & + & - & - & + \\
5 & + & + & + & + & + \\
\hline
\end{tabular}

Medium 1-XDM 2 . The following media do not contain amino acids: medium $2-\mathrm{XDM}_{2}$ addition of $\mathrm{KNO}_{3}(0.2 \mathrm{~g} / \mathrm{L})$; medium $3-\mathrm{XDM}_{2}$ addition of $\mathrm{NH}_{4} \mathrm{NO}_{3}(0.2 \mathrm{~g} / \mathrm{L})$; and medium $4-\mathrm{XDM}_{2}$ addition of $\mathrm{KNO}_{3}(0.2 \mathrm{~g} / \mathrm{L})$ and agar $(15 \mathrm{~g} / \mathrm{L})$.

Table 1 - Activity of enolases extracted from chicken muscle and liver, from bacteria DH5 $\alpha$, JM101, and X. fastidiosa, and activity of recombinant enolases. Recombinant enolase and enolase from chicken muscle and liver were extracted using two different buffers. Activity was estimated using 2-phosphoglycerate (2-PGA) and phosphoenolpyruvate (PEP) and 10 $\mu \mathrm{L}$ of the supernatant of these solutions. ND - not detected.

\begin{tabular}{|c|c|c|c|c|c|}
\hline & \multicolumn{4}{|c|}{ Activity $\left(10^{-4}\right)$ (min. $\mu$ g protein) } & \multirow[b]{2}{*}{$\begin{array}{c}\text { After urea addition and } \\
\text { removal }\end{array}$} \\
\hline & Buffer 1 (2-PGA) & Buffer 1 (PEP) & Buffer 2 (2-PGA) & Buffer 2 (PEP) & \\
\hline Liver & 1.91 & 1.39 & 3.72 & 2.51 & ND \\
\hline Muscle & 1.73 & 3.68 & 2.85 & 5.47 & ND \\
\hline DH5 $\alpha$ & 4.53 & 3.514 & - & - & - \\
\hline JM101 & 2.50 & 1.912 & - & - & - \\
\hline X. fastidiosa & ND & ND & ND & ND & - \\
\hline Recombinant enolase & ND & ND & ND & ND & - \\
\hline $\begin{array}{l}\text { Recombinant enolase after } \\
\text { activation }\end{array}$ & ND & ND & ND & ND & - \\
\hline
\end{tabular}


ria and eukaryotes, glycolysis or the EmbdenMeyerhoff-Parnas pathway is the pathway used to metabolize monosaccharides, which come directly from the environment or from the breakdown of several types of carbohydrates. As a rule, the initial substrate is glucose6-phosphate or fructose-6-phosphate. These pathways ultimately produce pyruvate, which is the main intermediate of central metabolism, since it is present in several catabolic and anabolic pathways.

Concerning the energy metabolism, all glycolytic enzymes were identified in the genome of Xylella fastidiosa. Gluconeogenesis may be cited as one of the apparently absent pathways, since the enzymes which are necessary to overcome the irreversible step in glycolysis, namely pyruvate carboxylase, phosphoenolpyruvate carboxykinase, and fructose-1,6-bisphosphatase, were not identified (Simpson et al., 2000).

The importance of gluconeogenesis seems to be the production of glucose or derivatives, which are phosphorylated at positions 1 or 6 . These could then be used in biosynthetic processes, such as the synthesis of cell walls, using non-glycidic compounds as intermediates of the citric acid cycle, glycerol, lactate, and gluconeogenic amino acid. Thus, the breakdown of such compounds may overcome the lack of glucose necessary for metabolism (Voet and Voet, 1995).

It is also possible that there are non-homologous genes among the large number of unidentified $X$. fastidiosa genes, which may compensate for steps in such critical pathways (Simpson et al., 2000). The initial trend is to consider that this is a case of substitution of non-homologous genes. However, if the enzyme fructose 1,6-biphosphatase is confirmed to be absent in $X$. fastidiosa, this might also be an explanation for the reported long duplication time of this microorganism. Without a functional gluconeogenesis, $X$. fastidiosa would not have any other substrate other than absorbed carbohydrates to synthesize the cell walls. Consequently, there would be a continuous competition for the use of carbohydrates, with a consequent decrease in the rate of cellular wall synthesis and an increase in duplication time (Ferreira, 2000).

For the sake of a comparison, there are two species of bacteria already sequenced and annotated that are genetically close to X. fastidiosa: E. coli and Haemophillus influenzae. The fact that the ORFs of the enzymes of most metabolic pathways have already been identified may be due only to a greater similarity between the proteins of $X$. fastidiosa and the ones in the database. On the other hand, since xylem is a poor growth medium, as compared to the habitat of animal pathogens, we could infer that $X$. fastidiosa needs a complete central metabolism and has to synthesize most, if not all, of its metabolic intermediates.

In organisms in which glycolysis is absent, and even in organisms that use glycolysis as the main monosaccharide breakdown pathway, there is a metabolic pathway, or variations of it, called the Entner-Doudoroff pathway. This pathway uses glucose-6-phosphate as an initial substrate, proceeding towards glucono-1,5-lactone-6phosphate, 6-phosphogluconate, and 2-keto-3-deoxy-6phosphogluconate (Figure 2). Usually, the pathway is used in bacteria for the glucoronate metabolism, producing a liquid energy balance of $1 \mathrm{~mol}$ of ATP per mol of glucoronate or glucose, depending on the initial substrate (Romano and Conway, 1996).

However, in the Archaea bacterium Pyrococcus furiosus, both a hexokinase and a phosphofructokinase were discovered which are ADP-dependent and form AMP. This sugges that glycolysis was used as glucose metabolism pathway, which was confirmed by enzymatic activity and $\mathrm{C}^{13}$ studies (Kengen et al., 1994). This finding reinforces the theory that a simple comparison of the sequences of homologous proteins is a preliminary mechanism for the identification of metabolic pathways, however, it must not be considered as decisive, since there is a possibility that analogous enzymes may exist performing similar functions in a completely different way from the one that has already been described.

ORFs were identified in the $X$. fastidiosa genome encoding the most common glycolysis enzymes and also the enzymes of the Entner-Doudoroff pathway, showing its similarity to $E$. coli. Thus, in the presence of available carbohydrates, these pathways can guarantee the production of pyruvate.

The physiological role of the Entner-Doudoroff pathway in E. coli is still unclear. The finding of the glucose dehydrogenase-dependent pyrroloquinoline quinonae (PQQ), which catalyzes the oxidation of glucose to gluconic acid in the periplasm, suggested an alternative route for glucose catabolism in E. coli (Hommes et al., 1984). In X. fastidiosa, two ORFs encoding this gene were found (XF-1740 and XF-2259). A low concentration of phosphate indirectly promotes the use of the Entner-Doudoroff pathway, by providing access of PQQ into the periplasm rather than directly, by derepressing edd (that codifies 6-phosphogluconate dehydratase) and eda (that codes 2-keto-3-deoxy-6-phosphogluconate (KDPG) aldolase) (Fliege et al., 1992).

An analysis of the genome sequences that have already been published and of those partially completed indicates that the Entner-Doudoroff pathway is present in several organisms. This is not surprising, since enzymes of the Entner-Doudoroff pathway have been shown to be widely distributed amongst bacteria and to be present in all three phylogenetic domains, including the most deeply rooted Archaea (Peekhaus and Conway, 1998). Recently, three organisms phylogenetically close to $X$. fastidiosa were sequenced, namely Xanthomonas campestris pv. campestris, Xanthomonas axonopodis pv. citri (da Silva et al., 2002), and the Termecula strain of $X$. fastidiosa, which is responsible for Pierce's Disease in grapevine. It was pro- 


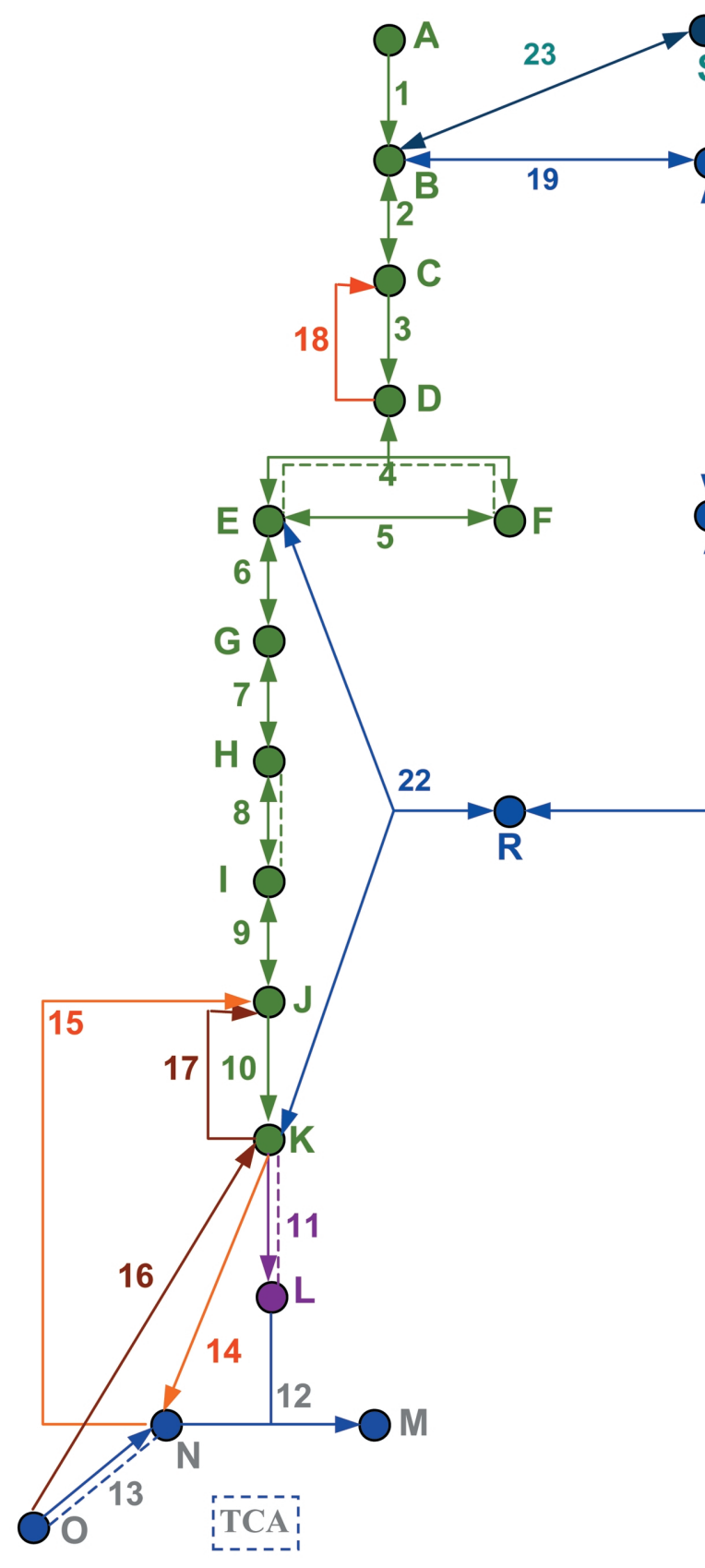

\section{$\underline{\text { Substances }}$}
A Glucose
B Glucose-6-phosphate
C Fructose-6-phosphate
D Fructose-1,6-bisphosphate
E Glyceraldehyde-3-phosphate
F Dihydroxyacetonephosphate
G 1,3-Bisphosphoglycerate

$\begin{array}{ll}\text { H } & \text { 3-Phosphoglycerate } \\ \text { I } & \text { 2-Phosphoglycerate } \\ \text { J } & \text { Phosphoenolpyruvate } \\ \text { K } & \text { Pyruvate } \\ \text { L } & \text { Acetyl-CoA } \\ \text { M } & \text { Citrate } \\ \text { N } & \text { Oxaloacetate }\end{array}$

O Malate

P Glucono-1,5-lactone-6-phosphate

Q 6-Phosphogluconate

$\mathrm{R}$ 2-Dehydro-3-deoxiphosphogluconate

$\mathrm{S}$ Glucose-1-phosphate
Aldolase

\section{DhnA}

Dehydrogenase

7 3-Phosphoglycerate Kinase

8 Phosphoglycerate Mutase 1 / Phosphoglycerate Mutase (Fructose-2,6bisphosphatase) / Phosphogliceromutase

9 Enolase

2110 Pyruvate Kinase

11 Pyruvate Dehydrogenase / Pyruvate Ferredoxin Oxidoredutase

12 Citrate Synthetase

13 Bacterial/ Arquebacterial Malate Dehydrogenase

Gluconeogenesis

14 Pyruvate Carboxylase

15 Phosphoenolpyruvate Carboxykinase

16 Malate Oxidoredutase (Malic Enzyme)

17 Phosphoenolpyruvate Syntethase

18 Fructose-1,6-bisphosphatase

Phosphorylated Entner-Doudoroff

19 Glucose-6-phosphate Dehydrogenase

20 6-Phosphogluconolactonase

21 6-Phosphogluconate Dehydratase

22 2-Dehydro-3-deoxiphosphoogluconate Aldolase

23 Phosphoglycomutase

Figure 2 - Glycolytic pathways: glycolysis, gluconeogenesis, and Entner-Doudoroff (A.J.S. Ferreira). 
posed that all of them possess the two previously described enzymes, responsible for the active pathway. This idea is corroborated by the great similarity of habitats of these phytopathogenic organisms and the constituents of these habitats.

In a comparative analysis of the glycolytic enzymes from 17 completely sequenced genomes (Archaea, bacteria and yeast), a surprising plasticity of the glycolytic pathway was detected. Enzymes of the Entner-Doudoroff pathway are not so well conserved, when compared to second-phase enzymes of glycolysis. This fact might be explained by the coexistence of the two pathways in several species (Dandekar et al., 1999).

In studies of the glucose-repressive genes in Bacillus subtilis, which are genes induced after the consumption of glycolytic carbon sources, when glucose was added, the repression of the expression of these genes was maintained. This fact is due to the presence in B. subtilis of CcpA, a catabolism control protein. Using microarray analyses, the authors detected 66 glucose-repressive genes, 22 of which were at least partially under CcpA-independent control mechanisms (Yoshida et al., 2001).

\section{References}

Alfenas AC (Ed) (1998) Eletroforese de proteínas e isoenzimas de fungos e essências florestais. Viçosa: Sociedade de Investigações Florestais.

Bhattacharyya A, Stilwagen S, Reznik G, Feil H, Eil SW and Anderson I (2002) Draft sequencing and comparative genomics of Xylella fastidiosa strains reveal novel biological insights. Gen Res 12:1556-1563.

Birren B, Green ED, Klapholz, Myers RM and Roskams J (1997) Genome Analysis. A Laboratory Manual. Cold Spring Harbor Laboratory Press.

Chang CJ, Garnier M, Zreik L, Rossetti V and Bove JM (1993) Culture and serological detection of the xylem-limited bacterium causing citrus variegated chlorosis and its identification as a strain of Xylella fastidiosa. Curr Microbiol 27:137-42.

da Silva ACR, Ferro JA, Reinach FC, Farah CS, Furlan LR, Quaggio RB, Monteiro-Vitorello CB, Van Sluys MA, Almeida NF, Alves LMC, do Amaral AM, Bertolini MC, Camargo LEA, Camarote G, Cannavan F, Cardozo J, Chambergo F, Ciapina LP, Cicarelli RMB, Coutinho LL, Cursino-Santos JR, El-Dorry H, Faria JB, Ferreira AJS, Ferreira RCC, Ferro MIT, Formighieri EF, Franco MC, Greggio CC, Gruber A, Katsuyama AM, Kishi LT, Leite RP, Lemos EGM, Lemos MVF, Locali EC, Machado MA, Madeira AMBN, Martinez-Rossi NM, Martins EC, Meidanis J, Menck CFM, Miyaki CY, Moon DH, Moreira LM, Novo MTM, Okura VK, Oliveira MC, Oliveira VR, Pereira HA, Rossi A, Sena JAD, Silva C, de Souza RF, Spinola LAF, Takita MA, Tamura RE, Teixeira EC, Tezza RID, Trindade dos Santos, M, Truffi D, Tsai SM, White FF, Setúbal JC and Kitajima JP (2002) Comparison of the genomes of two Xanthomonas pathogens with differing host specificities. Nature 417:459-463.
Dandekar T, Schuster S, Snel B, Huynen M and Bork P (1999) Pathway alignment: application to the comparative analysis of glycolytic enzymes. J Biochem 343:115-124.

Davis BJ (1964). Disc electrophoresis. Method and application to human serum proteins. Ann NY Acad Sci 121:404-427.

Ferreira AJS (2000) Seqüenciamento de parte do genoma de Xylella fastidiosa e análise do metabolismo de carboidratos no genoma anotado. 120 f. Dissertação (mestrado em Bioquímica). Instituto de Química, Universidade de São Paulo, São Paulo.

Fliege R, Tong S, Shibata A, Nickerson KW and Conway T (1992) The Entner-Doudoroff pathway in Escherichia coli is induced for oxidative glucose metabolism via pyrroloquinoline quinone-dependent glucose dehydrogenase. Appl and Environm Microbiol 58 (12):3826-3829

Glover DM and Hames BD (1995) DNA Cloning 2: A practical approach - Expression systems. 2nd. Ed. New York: Oxford University Press, pp 67-69.

Griffin HG and Griffin AM (1993) Methods in molecular biology. DNA sequencing protocols. Totowa, Humana Press Inc., NJ, 23 pp.

Hartree EF (1972) Determination of protein: a modification of the Lowry method that gives a linear photometric response. Annal Biochem 48:422-427.

Hartung JS, Bereta MJG, Brlansky RH, Spisso J and Lee RF (1994) Citrus variegated chlorosis bacterium: axenic culture, pathogenicity and relationships with other strains of Xylella fastidiosa. Phytopathol 64:591-597.

Hommes RWJ, Postma RW, Neijssel OM, Tempest DW, Dokter $P$ and Duine JA (1984) Evidence for quinoprotein glucose dehydrogenase apoenzyme in several strains of Escherichia coli. FEMS Microbiol Lett 24:1904-1910.

Kengen SWM, de Bok FAM, van Loo ND, Dijkema C, Stams AJM and de Vos WM (1994) Evidence for the operation of a novel Embden-Meyerhof pathway that involves ADPdependent kinases during sugar fermentation by Pyrococcus furiosus. J Biol Chem 269 (26):17537-17541.

Kustrzeba-Wójcicka I and Golczak M (2000) Enolase from Candida albicans - purification and characterization. Comp. Biochem. Physiol B 126:109-120.

Laemmli VK (1970) Cleavage of structural proteins during the assembly of the head bacteriophage T4. Nature 277:680-685.

Lemos EGM, Alves LMC and Campanharo JC (2002) Genomics-based design of defined growth media for the plant pathogen Xylella fastidiosa. FEMS Microbiol Lett 219:39-45.

Machado M (1997) Citrus Variegated Chlorosis (CVC), a new destructive citrus disease in Brazil, and the xylem-limited bacteria, Xylella fastidiosa. http://www.dcc.unicamp.br/ genoma/xylella.html/.

Monteiro PB, Lataro RC, Ferro JA and Reinach FC (1994) Functional $\alpha$-tropomyosin produced in E.coli: a dipeptide extension can substitute the amino terminal acetyl group. J Biol Chem 269:10461-10466.

Peekhaus N and Conway T (1998) Whats for dinner? EntnerDoudoroff metabolism in Escherichia coli. J Bacteriol 180(14):3495-3502.

Purcell AH and Hopkins DL (1996) Fastidious xylem-limited bacterial plant pathogens. Annu Rev Phytopathol 34:131151. 
Rivoal J, Smith CR, Moraes TF, Turpin DH and Plaxton WC (2002) A method for activity stain after native polyacrylamide gel electrophoresis using a coupled enzyme assay and fluorescence detection: application to the analysis of several glycolytic enzymes. Annal Biochem 300:94-99.

Romano AH and Conway T (1996) Evolution of carbohydrate metabolic pathways, 14th Forum in Microbiology. Res Microbiol 147:448-455.

Rossetti V, Garnier M, Bové JM, Bereta MJG, Teixeira ARR, Quagio JA and de Negri JD (1990) Présence de bactéries dans le xylème d'orangers atteints de chlorose variégée, une nouvelle maladie des agrumes au Brésil. C R Acad Sci, Paris 310:345-9.

Rossetti V, Gonzales MA and Donadio LC (1998) In: Donadio LC and Moreira CS (eds) History, in "Citrus Variegated Chlorosis", Bebedouro.

Sambrook J, Fritsch EF and Maniatis T (1989) Molecular Cloning: A Laboratory Guide, 2nd Edition, Cold Spring Harbor Laboratory Press, Cold Spring Harbor, New York.

Simpson AJ, Reinach FC, Arruda P, Abreu FA, Acencio M, Alvarenga R, Alves LM, Araya JE, Baia GS, Baptista CS, Barros MH, Bonaccorsi ED, Bordin S, Bove JM, Briones MR, Bueno MR, Camargo AA, Camargo LE, Carraro DM, Carrer H, Colauto NB, Colombo C, Costa FF, Costa MC, Costa-Neto CM, Coutinho LL, Cristofani M, Dias-Neto E, Docena C, El-Dorry H, Facincani AP, Ferreira AJ, Ferreira VC, Ferro JA, Fraga JS, Franca SC, Franco MC, Frohme M, Furlan LR, Garnier M, Goldman GH, Goldman MH, Gomes SL, Gruber A, Ho PL, Hoheisel JD, Junqueira ML, Kemper EL, Kitajima JP, Krieger JE, Kuramae EE, Laigret F, Lambais MR, Leite LC, Lemos EG, Lemos MV, Lopes SA, Lopes CR, Machado JA, Machado MA, Madeira AM, Madeira HM, Marino CL, Marques MV, Martins EA, Martins
EM, Matsukuma AY, Menck CF, Miracca EC, Miyaki CY, Monteriro-Vitorello CB Moon DH, Nagai MA, Nascimento AL, Netto LE, Nhani A Jr, Nobrega FG, Nunes LR, Oliveira MA, de Oliveira MC, de Oliveira RC, Palmieri DA, Paris A, Peixoto BR, Pereira GA, Pereira HA Jr, Pesquero JB, Quaggio RB, Roberto PG, Rodrigues V de M, Rosa AJ, de Rosa VE Jr, de Sa RG, Santelli RV, Sawasaki HE, da Silva AC, da Silva AM, da Silva FR, da Silva WA Jr, da Silveira JF, Silvestri ML, Siqueira WJ, de Souza AA, de Souza AP, Terenzi MF, Truffi D, Tsai SM, Tsuhako MH, Vallada H, Van Sluys MA, Verjovski-Almeida S, Vettore AL, Zago MA, Zatz M, Meidanis J and Setubal JC (2000) The genome sequence of the plant pathogen Xylella fastidiosa. Nature. 406:151-157.

Voet D and Voet JG (1995) Biochemistry, 2nd edition, John Wiley \& Sons, New York.

Vuillard L and Freeman A (2001) Preparation of active proteins from inclusion bodies.nwfsv.noaa.gov/protocols/inclusion. html.

Wells J, Raju B, Jung H, Weisburg W, Mandelco-Paul L and Brenner D (1987) Xylella fastidiosa gen nov, sp nov gram negative, xylem limited fastidious plant bacteria related to Xanthomonas ssp. Int J of Syst Bacteriol 37:136-143.

Wold F (1971) In: Boyer, PD (ed) In the Enzymes, v 5, 3rd ed New York. Academic Press. pp 499-538.

Yoshida K, Kobayashi K, Miwa Y, Kang C-M, Matsunaga M, Yamaguchi H, Tojo S, Yamamoto M, Nishi R, Ogasawara N, Nakayama T and Fujita Y (2001) Combined transcriptome and proteome analysis as a powerful approach to study genes under glucose repression in Bacillus subtilis. Nucleic Acids Res 29(3):683-692.

Editor: Darcy Fontoura de Almeida 